\title{
Effects of Hydrogel Use in Cariniana pyriformis (Lecythidaceae) Seedlings Under Different Water Regimes
}

\author{
Ingrid Vanessa Ríos ${ }^{1}$ \\ Andrés Iván Prato ${ }^{2}$ (i) \\ Andrés Felipe Castaño ${ }^{1}$
}

\begin{abstract}
The effect of hydrogel $(0,3,6$, and 9 g per seedling) on the survival and growth of Cariniana pyriformis seedlings under different water regimes (absence of irrigation, $60 \%$ and $100 \%$ field capacity) in a sandy loam soil was assessed. The experiment was carried out in an agricultural nursery with drip irrigation, implementing a completely randomized block design in a split-plot scheme. After 20 weeks of evaluation in both treatments with irrigation, the maximum dose showed a slight increase (9\%) in stem diameter and seedling height compared with the control treatment, although the aerial and root dry biomass did not show differences. For the treatment without irrigation, the survival had a linear response with increasing doses, from $24 \%$ ( 0 g per seedling) to $65 \%$ ( 9 g per seedling). C. pyriformis responds positively to hydrogel when a severe water deficit occurs.
\end{abstract}

Keywords: Colombian mahogany, hydro retainer polymer, reforestation, water stress.

\section{INTRODUCTION AND OBJECTIVES}

Currently, the policies and regulations that govern the activities related with the use of wood in Colombia have been insufficient to counteract illegality, indiscriminate use, and the scarce organization in the commercialization of timber species (PROFOR, 2017). Moreover, the lack of silvicultural knowledge places native species at a disadvantage compared to exotic species that have traditionally been cultivated in the country, such as Pinus spp., Eucalyptus spp., Acacia mangium Willd., Tectona grandis L.f. and Gmelina arborea Roxb. ex Sm. (PROFOR, 2017).

The abarco (Cariniana pyriformis Miers), commercially known as Colombian mahogany, is characterized by its arborescent habit, reaching up to $50 \mathrm{~m}$ tall, simple leaves of crenate margins, pink petals, and turbinated fruits (Prance \& Mori, 1979; Mori et al., 2019). In addition, due to the properties of its wood, such as hardness and resistance to weathering, the abarco is of high economic value and has been widely exploited, which has led it to be categorized locally as Critically Endangered (CR) (Salinas \& Cárdenas, 2007; Cárdenas et al., 2015), and globally as Near Threatened (NT) (IUCN, 2019). In this regard, its conservation in agroforestry systems with cocoa has been promoted as a strategy to improve the production of this crop (Agudelo-Castañeda et al., 2018; Suarez et al., 2018). C. pyriformis is distributed from northwestern South America to Venezuela (Prance \& Mori, 1979; Mori et al., 2019).

In Colombia, the species grows in humid tropical forests between 0 and $800 \mathrm{~m}$ of altitude, from the north of the biogeographic Chocó region to the Catatumbo moist forests (Celis, 2016; Mori et al., 2019). These ecoregions are characterized by the absence of a defined dry season and with more than 3,500 $\mathrm{mm}$ of annual precipitation (Moreno \& Del Valle, 2015). Furthermore, it grows in the inter-Andean valleys of the Magdalena River with a bimodal precipitation regime (Pelaez et al., 2018). However, its presence has also been reported in the tropical dry forest of the Caribbean coast, a biome characterized by having an annual rainfall of less than 2,000 $\mathrm{mm}$ and one or two periods of drought lasting more than three months (accumulated rainfall $<300 \mathrm{~mm}$ ) (Pizano \& García, 2014; Espitia et al., 2017).

Hydrogels (i.e., super-absorbent polymers), which have a water absorption capacity of up to 300 times their volume, releasing the water in a controlled manner to the seedlings, have been used for 30 years or more in agriculture and the timber industry (Crous,

${ }^{1}$ Universidad Industrial de Santander, Facultad de Ciencias, Escuela de Biología, Bucaramanga, Santander, Colombia

${ }^{2}$ Corporación Colombiana de Investigación Agropecuaria (AGROSAVIA), Centro de Investigación La Suiza, Santander, Colombia 
2017). Due to a higher availability of water and nutrients in the soil, hydrogels increase the growth and survival of seedlings as reported for Eucalyptus dunnii Maiden (Navroski et al., 2015), Coffea arabica L. (Souza et al., 2016) and Pinus patula Schiede ex Schltdl \& Cham (Mudhanganyi et al., 2018); and species from the Cerrado in Brazil (i. e. Enterolobium contortisiliquum (Vell.) Morong, Fonseca et al., 2017; Pontes Filho et al., 2018). However, the time and application methods of the hydrogel, as well as the irrigation frequency, polymer type, texture and other soil physical properties have an influence on the optimal doses and affect its performance depending on the species (Crous, 2017).

C. pyriformis is a semi-deciduous species (Pelaez et al., 2018) that is probably adapted to drought, considering the climates where it grows. However, several factors such as the non-uniformity in the growth of the plantation and the costs associated to dead seedling replacement, limit conservation and commercial reforestation projects (Barbosa et al., 2013; Fonseca et al., 2017). Accordingly, the aim of this study was to evaluate the survival and growth of $C$. pyriformis seedlings using hydrogel under different water regimes.

\section{MATERIALS AND METHODS}

\subsection{Plant material}

The study was carried out during the period from April to August of 2019 in the municipality of Rionegro, department of Santander, Colombia ( $7^{\circ} 22^{\prime} 10^{\prime \prime} \mathrm{N}, 73^{\circ} 10^{\prime} 39^{\prime \prime} \mathrm{W} ; 550 \mathrm{~m}$ of altitude), corresponding to a humid tropical forest. Seeds of $C$. pyriformis were purchased from the company Semicol, originally obtained from the municipality of San Luis, Antioquia. Once the seedlings reached one month of age, these were transplanted to conical tubes ( $8 \mathrm{~cm}$ diameter $\mathrm{x} 25 \mathrm{~cm}$ height) and planted in a substrate composed of $60 \%$ soil $+20 \%$ river sand $+20 \%$ commercial compost obtained from composting poultry manure. The seedlings were maintained for five months in agricultural nursery covered with black monofilament screen and mesh to offer $65 \%$ of shading.

\subsection{Soil characterization and hydrogel application}

Seedlings with an average of $60 \mathrm{~cm}$ in height and $5 \mathrm{~mm}$ in stem diameter were transplanted into plastic bags $(15 \mathrm{~cm}$ diameter $\mathrm{x} 30 \mathrm{~cm}$ height), at a density of 12 seedlings per $\mathrm{m}^{2}$. They were placed in an agricultural nursery with $50 \%$ shading given by a plastic coverage (Agrofrio X) and drip irrigation to simulate their planting in the field, using an automated timer system and self-compensated drippers with a flow of $1.2 \mathrm{~L} \mathrm{~h}^{-1}$. The temperature and relative humidity were recorded every 10 minutes using a data logger (CEM, DT-172) with averages of $26 \pm 5^{\circ} \mathrm{C}$ and $88 \pm 5.5 \%$, respectively.

Initially, the bags were filled up to $70 \%$ of their capacity with sandy loam soil, adding the slow-release fertilizer Basacote Plus $6 \mathrm{M}$ (16-8-12-5; $\left.\mathrm{N}-\mathrm{P}_{2} \mathrm{O}_{5}-\mathrm{K} 2 \mathrm{O}-\mathrm{S}\right)$, at a rate of $2 \mathrm{~g}$ per liter. $\mathrm{A}$ soil sample was collected for chemical characterization, and an undisturbed soil sample was obtained with an aluminum ring to calculate bulk density and moisture retention curve (tensions of $0,-10,-33$, and $1,500 \mathrm{kPa}$ ). The analyses were carried out in the Laboratorio Nacional de Suelos of the Instituto Geográfico Agustín Codazzi (IGAC), in Bogotá (see Table 1).

Table 1. Physical and chemical properties and water retention curve (WRC) of the soil used in the experiment.

\begin{tabular}{|c|c|c|}
\hline \multicolumn{3}{|c|}{ Physical properties } \\
\hline soil texture ${ }^{(1)}$ & & \\
\hline sand & \multirow{3}{*}{$(\%)$} & 67.4 \\
\hline Silt & & 142 \\
\hline Clay & & 18.4 \\
\hline bulk density ${ }^{(2)}$ & \multirow{2}{*}{$\mathrm{g} \mathrm{cm}^{-3}$} & 1.2 \\
\hline real density & & 2.6 \\
\hline \multicolumn{3}{|c|}{ WRC (curve tension $\mathrm{kPa}$ ) } \\
\hline 0 & \multirow{4}{*}{$\%$} & 42.5 \\
\hline$-10^{(3)}$ & & 18.0 \\
\hline-33 & & 13.8 \\
\hline$-1,500^{(4)}$ & & 6.5 \\
\hline
\end{tabular}

\begin{tabular}{ccc}
\multicolumn{3}{c}{ Chemical properties } \\
$\mathrm{pH}^{(5)}$ & & 6.7 \\
$\mathrm{E}^{(5)}$ & $\mathrm{dS} \mathrm{m}{ }^{-1}$ & 0.16 \\
$\mathrm{O}^{(5)}{ }^{(6)}$ & ${\mathrm{g} 100 \mathrm{~g}^{-1}}$ & 0.72 \\
$\mathrm{~N}^{(7)}$ & $\%$ & 0.11 \\
$\mathrm{P}^{(8)}$ & & 9.6 \\
$\mathrm{~S}^{(9)}$ & $\mathrm{mg} \mathrm{kg}^{-1}$ & 3.6 \\
$\mathrm{Fe}^{(9)}$ & & 29.8 \\
$\mathrm{Ca}^{+2(10)}$ & & 5.1 \\
$\mathrm{Mg}^{+2(10)}$ & $\mathrm{cmol}_{(+)} \mathrm{kg}^{-1}$ & 0.7 \\
$\mathrm{~K}^{+(10)}$ & & 0.1 \\
$\mathrm{Na}^{(10)}$ & & 0.14 \\
\hline
\end{tabular}

${ }^{(1)}$ bouyoucos method. ${ }^{(2)}$ undisturbed sample. ${ }^{(3)}$ field capacity was considerate at $-10 \mathrm{kPa} .{ }^{(4)}$ permanent wilting point was considerate at $-1,500 \mathrm{kPa} .{ }^{(5)} \mathrm{pH}$ and electrical conductivity (E.C) at a soil: water ratio of 1:5. ${ }^{(6)}$ organic matter (O.M) by the Walkey and Black method. ${ }^{(7)}$ Kjeldahl by colorimetry. ${ }^{(8)}$ monobasic calcium phosphate. ${ }^{(9)}$ modified Olsen. ${ }^{\left({ }^{10}\right)} 1 \mathrm{~N}$ ammonium acetate with a $\mathrm{pH}$ of 7. 
According to the seller, the used hydrogel (Hidrokeeper) contains molecules of acrylamide and potassium acrylate with an absorption capacity 300 times its weight, density of $0.8 \mathrm{~g} \mathrm{~cm}^{-3}$, usable $\mathrm{pH}$ index from 5 to 9 , insoluble in water, particle size from 0.2 to $5 \mathrm{~mm}$ and a shelf life of five years. Four doses of hydrogel were evaluated $(0,3,6$, and $9 \mathrm{~g}$ per seedling). The total amount was hydrated for 72 hours, with $300 \mathrm{ml}$ of water per dry $\mathrm{g}$ of the hydrogel. During the transplant and according to the volume per dose, half of the hydrogel was applied to the bottom of the bag and then covered with a layer of soil, and the other half was spread around the stem.

Three water regimes were evaluated according to the irrigation depths, i.e., absence of irrigation, $60 \%$, and $100 \%$ field capacity (FC) of soil. Following the transplant, the seedlings without irrigation were kept for 8 days at FC, whereas those of the other water regimes remained 40 days at FC. The soil moisture content was calculated weekly using the weight loss of two plastic bags per water regime, employing an electronic balance $(0.1 \mathrm{~g})$. The water volume needed to restore the humidity to $100 \%$ and $60 \%$ FC was applied every Tuesday and Saturday in three turns (08:00, 11:00 and 16:00 h), according to Equation 1:

$$
I d=F C^{*} D b^{*} B d{ }^{*} A b^{\star} I e
$$

Where $I d$ is the irrigation depth (mm), FC is the field capacity of soil at $-10 \mathrm{kPa}$ (\% moisture by weight), $D b$ is the depth of the plastic bag $(\mathrm{cm}), B d$ is the bulk density of sandy loam soil $\left(\mathrm{g} \mathrm{cm}^{-3}\right), A b$ is the area $\left(\mathrm{cm}^{2}\right)$ of the plastic bag, and $I e$ is the drip irrigation system efficiency $(90 \%)$.

\subsection{Experimental design and data analysis}

A randomized complete block design was adopted in a split-plot scheme with three repetitions of five seedlings each; the main plot corresponded to the three water regimes according to the irrigation depth (absence of irrigation, $60 \%$, and $100 \%$ FC of soil) and the subplot corresponded to the four doses of hydrated hydrogel (0, 3, 6 and 9 g per seedling). For the treatment without irrigation, the wilting stages were recorded every week (on Thursday) during 20 weeks ( 142 days) for each seedling, using a classification based on six visual characteristics (see Table 2; adapted from Engelbrecht \& Kursar, 2003), and calculating the duration in days of each of the categories.

Table 2. Wilting stages of $C$. pyriformis seedlings based on external characteristics.

\begin{tabular}{|c|c|c|}
\hline \multicolumn{2}{|r|}{ Stage } & Visual characteristics \\
\hline 0 & Normal & No signs of wilting or water stress. \\
\hline 1 & Slightly wilted & Some leaves lose turgidity, but none are rolled or folded. \\
\hline 2 & Wilted & $\begin{array}{l}\text { Leaves begin to hang and have lost turgidity. The leaf angle is close to }-45^{\circ} \text { in relation to } \\
\text { the horizontal plane. }\end{array}$ \\
\hline 3 & Severely wilted & Beginning of the generalized leaf necrosis (with gray-green to gray-brown areas). \\
\hline 4 & Nearly dead & $\begin{array}{l}\text { Most of the leaves are necrotic, some young leaves still green near the midrib. The stem is } \\
\text { alive and is distinguished by its color and elasticity. }\end{array}$ \\
\hline 5 & Dead & Necrosis of all leaves and the stem has lost its elasticity. \\
\hline
\end{tabular}

Adapted from Engelbrecht \& Kursar (2003).

Two variables were measured biweekly: plant height $(\mathrm{H})$, measured with a flexometer $(0.1 \mathrm{~cm})$ from the stem base to the apical meristem, and stem diameter (SD), measured with a digital caliper $(0.01 \mathrm{~mm})$. At the end of the evaluation period, the survival percentage was established as 1 for seedlings that were alive, and zero (0) for dead seedlings, i.e., equivalent to a range of $0-100 \%$. Also, four randomly selected seedlings per treatment were used to calculate the dry mass of their aerial organs (DMA) and their dry root mass (DRM). This was carried out in a forced ventilation oven at $65^{\circ} \mathrm{C}$ until constant weight. Using these values, the Dickson's quality index was calculated according to Equation 2 (Dickson et al., 1960):

$$
D Q I=(D M A+D R M) /((H / S D)+(D M A / D R M))
$$

Where DQI corresponds to Dickson's quality index, $H[\mathrm{~cm}]$ to the plant height, $S D[\mathrm{~mm}]$ to the stem diameter, $D M A[\mathrm{~g}]$ to the dry mass of the aerial organs, and DRM [g] to the dry root mass.

The normality and homoscedasticity of the variance in the data were evaluated according to the Shapiro-Wilk and Levene's test, respectively. When significant differences $(p<0.05)$ were found in the variables DQI, DMA, DRM and duration of the water stress categories, the comparison of means was carried out with Tukey's test. On the contrary, if the assumptions were not fulfilled, the non-parametric Kruskal-Wallis test was performed. The dose interactions for each water regime in the height and stem diameter variables were unfolded when it was significant $(p<0.05)$ 
by the regression analysis, evaluating the linear and quadratic regression models. The one with the highest coefficient of determination $\left(R^{2}\right)$ and significance found by the $\mathrm{F}$ test was selected. The analyses were performed in the statistical program S.A.S, version 9.3.

\section{RESULTS AND DISCUSSION}

\subsection{Plant height and stem diameter}

The increase in height and stem diameter over time showed an interaction between the two factors evaluated. In the treatment without irrigation, these variables showed a negative quadratic response for the four hydrogel doses, although with lower

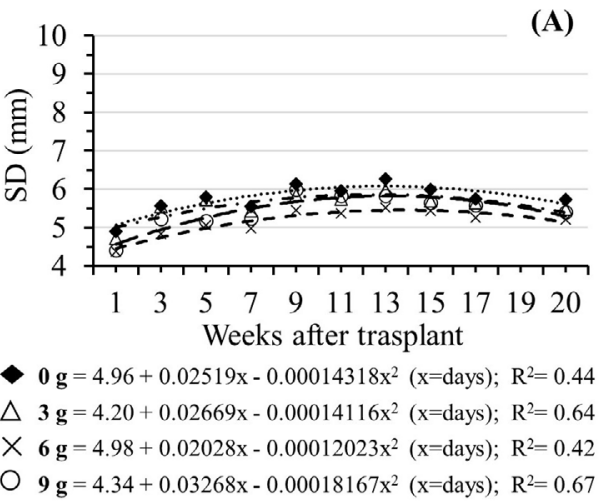

coefficient values for the dose of $0 \mathrm{~g}$ per seedling $\left(\mathrm{R}^{2}=0.6\right)$. The stem diameter reached a maximum on average at 81 days (between 5.81 and $6.07 \mathrm{~mm}$ ), whereas it was at 105 days for the plant height (between 70.4 and $72.3 \mathrm{~cm}$ ), thereafter a reduction of these values took place (see Figure 1A and 2A).

On the other hand, in the water regimes of $60 \%$ and $100 \% \mathrm{FC}$, the variables showed a positive linear trend for all hydrogel doses. After 20 weeks since the transplant, the application of $9 \mathrm{~g}$ per seedling increased the values of stem diameter (+ 14\%; 7.8 to $8.9 \mathrm{~mm}$ ) and height (+ 4\%; 93.5 to $97.2 \mathrm{~cm}$ ) compared to the control treatment in the water regime with $60 \%$ FC (see Figure 1B and 2B). This slight positive effect of the hydrogel was similar in the water regime with $100 \% \mathrm{FC}$ for stem diameter (+ 4.1\%; 9.0 to $9.4 \mathrm{~mm}$ ) and height (+ $8 \%$; 100 to $108 \mathrm{~cm}$ ), respectively (see Figure $1 \mathrm{C}$ and $2 \mathrm{C}$ ).

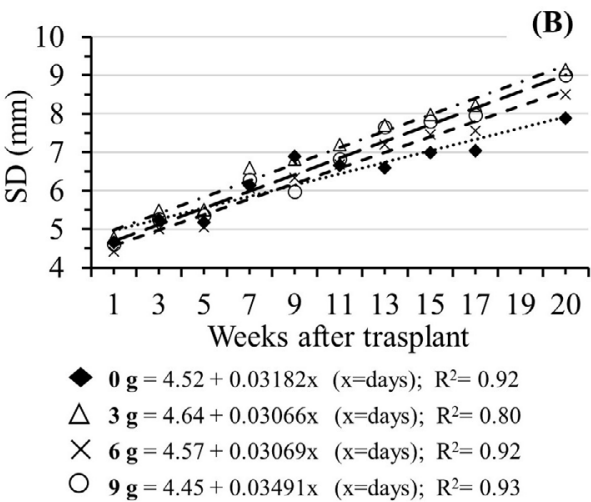

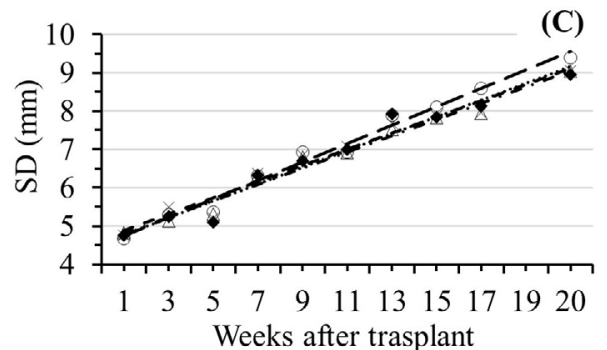

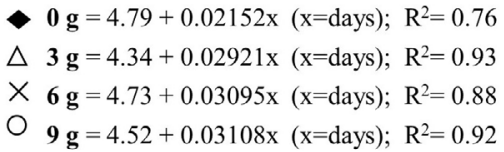

- $\mathbf{0} \mathbf{g}=4.79+0.02152 \mathrm{x}$ ( $\mathrm{x}=$ days $) ; \mathrm{R}^{2}=0.76$

$\times 6 \mathrm{~g}=4.73+0.03095 \mathrm{x}(\mathrm{x}=$ days $) ; \mathrm{R}^{2}=0.88$

$9 \mathrm{~g}=4.52+0.03108 \mathrm{x}(\mathrm{x}=$ days $) ; \mathrm{R}^{2}=0.92$

Figure 1. Stem diameter (SD) of $C$.pyriformis seedlings until 20 weeks after transplant at bags subjected to different hydrogel doses according to the water regime applied: in the absence of irrigation (A), $60 \% \mathrm{FC} \mathrm{(B),} \mathrm{and} \mathrm{100 \%} \mathrm{FC} \mathrm{(C).} \mathrm{FC=} \mathrm{field} \mathrm{capacity} \mathrm{of} \mathrm{soil.}$

The luminosity of $50 \%$ in which the $C$.pyriformis seedlings were maintained and the fact that the hydrogel has shown higher utility when used in severe water deficit, could have caused the poor differences between irrigation treatments. Another Cariniana species such as C. estrellensis (Raddi) Kuntze, considered as a non-pioneer species that grows in the semi-deciduous forest (Mata Atlântica) in Brazil, demonstrated its tolerance under full sun exposure (Gaburro et al., 2014). Pontes Filho et al. (2018) found that for Enterolobium contortisiliquum (Vell.) Morong, a pioneer tree species of savannas (Cerrado) in Brazil, the hydrogel dose that provided the best growth was lower in seedlings grown under full sun exposure ( $2 \mathrm{~g}$ ) compared to those grown in a nursery with $50 \%$ shading $(3.5 \mathrm{~g})$. The authors argued that higher evapotranspiration under full sun exposure induced lower doses to have a stronger effect. Perhaps $C$. pyriformis also has a high plasticity and requires a less intense level of shading during the early growth stages, which would be an aspect to be evaluated considering the natural conditions to which the species is adapted in its early development stages. 

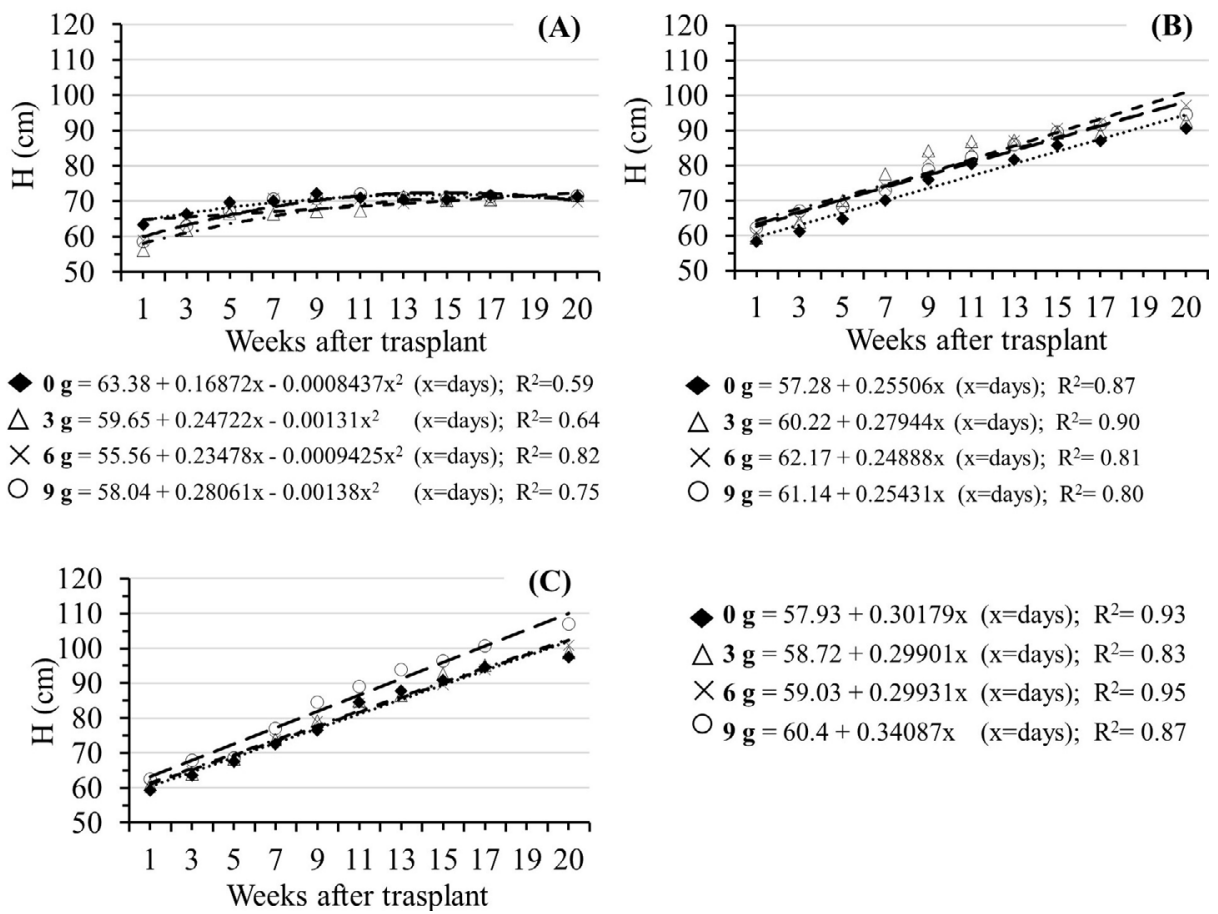

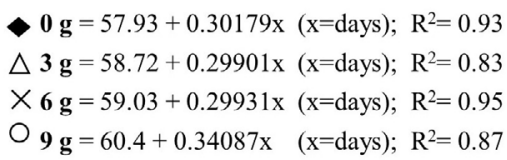

$\forall \mathbf{g}=63.38+0.16872 \mathrm{x}-0.0008437 \mathrm{x}^{2} \quad(\mathrm{x}=$ days $) ; \mathrm{R}^{2}=0.59$ $\times \mathbf{6 g}=55.56+0.23478 \mathrm{x}-0.0009425 \mathrm{x}^{2}(\mathrm{x}=$ days $) ; \mathrm{R}^{2}=0.82$

9 $\mathbf{g}=58.04+0.28061 \mathrm{x}-0.00138 \mathrm{x}^{2} \quad(\mathrm{x}=$ days $) ; \mathrm{R}^{2}=0.75$

$9 \mathrm{~g}=61.14+0.25431 \mathrm{x}(\mathrm{x}=$ days $) ; \mathrm{R}^{2}=0.80$

Figure 2. Plant height $(\mathrm{H})$ of $C$.pyriformis seedlings until 20 weeks after transplant at bags subjected to different hydrogel doses according to the water regime applied: in the absence of irrigation (A), $60 \% \mathrm{FC} \mathrm{(B),} \mathrm{and} \mathrm{100 \%} \mathrm{FC} \mathrm{(C).} \mathrm{FC=} \mathrm{field} \mathrm{capacity} \mathrm{of} \mathrm{soil.}$

In $P$. patula seedlings, there was an increase of $26 \%$ in height with the use of hydrogel ( 5 dry g per seedling in 1 liter of water) that contained in its composition, nutrients and beneficial fungi, planted in the middle of the dry season when evapotranspiration was maximal (Mudhanganyi et al., 2018). Additionally, in the tree Handroanthus ochraceus (Cham.), the optimal dose to increase the height and stem diameter with hydrogel combined with urea was 2 to $4 \mathrm{~g} \mathrm{~L}^{-1}$ applied during the nursery phase (Mews et al., 2015). In C. arabica seedlings evaluated with different irrigation levels and the presence or absence of hydrogel (a solution of $1.5 \mathrm{~L}$ per seedling), Souza et al. (2016) verified 120 days after transplant that only the irrigation factor influenced the plant height with a linear increase of $10 \%$, from a level of 75 to $100 \%$ of water available from a clay soil. The stem diameter showed an interaction between the factors, although with minimal differences for these two irrigation levels. Very similar results were found in the current study for the considered irrigation treatments.

The application of $9 \mathrm{~g}$ of hydrogel per seedling of C. pyriformis maintained at $60 \% \mathrm{FC}$ could replace the irrigation at $100 \%$ FC. In other words, to increase the positive effects of the hydrogel in future studies, the combination with other management techniques should be addressed, e.g., mineral fertilization, and thus, justify its use under these irrigation conditions $(60 \% \mathrm{FC})$.

\subsection{Dry mass of the aerial part, dry root mass and Dickson's quality index}

Only a simple effect could be noticed under the water regimes in DRM, DMA and DQI. In the treatment without irrigation, the biomass reduction compared to the treatments with irrigation was more drastic for the DMA $(-73 \%)$ than for the DRM $(-46 \%)$. A typical response to severe water deficit is the reduction of the leaf area through leaf necrosis because the seedling reduces water loss due to evapotranspiration at the expense of photosynthesis, and hence, biomass accumulation (Le Gal et al. 2015).

On the other hand, there were no significant differences in the treatments with irrigation, reaching on average $5.5 \mathrm{~g}$ of DRM, $17.5 \mathrm{~g}$ of DMA and 5.8 for DQI (see Table 3). As mentioned before, this might be related to the fact that the positive effects of the hydrogel are more noticeable in dry conditions. The absence of an adverse effect between the evaluated doses would indicate that the expansion of the hydrogel did not limit root development in the sandy loam soil.

The lower water availability with the $60 \%$ FC treatment did not increase the DRM, which could be due to a response mechanism associated mostly with the physiology of C. pyriformis than with morphological changes due to water stress. Markesteijn \& Poorter (2009) evaluated 62 tropical trees and concluded that the species vary strongly in their morphology and biomass translocation related with their 
tolerance to drought and shade after the first year, being the drought-tolerant species those that displayed higher root biomass. In parallel, Cordia trichotoma (Vell.) Arráb. ex Steud., a tree species native to South America, showed higher DQI values when greater irrigation sheets were applied due to the increase in DRM, although no influence of the hydrogel was observed (up to $4.5 \mathrm{~g}$ per seedling) (Brucker et al., 2017). The hydrogel did not affect the DQI of the C. pyriformis seedlings, which diverges with what was found by Mews et al. (2015) in seedlings of $H$. ochraceus. The DQI was also superior in the production of $E$. dunnii seedlings with $3.3 \mathrm{~g}$ per liter of hydrogel (Navroski et al., 2015).

Table 3. Mean values ( \pm standard deviation) for dry root mass (DRM), dry aerial mass (DMA), and Dickson's quality index (DQI) of C. pyriformis seedlings, according to different water regimes after 20 weeks from the transplant.

\begin{tabular}{|c|c|c|c|}
\hline Water regime & $\begin{array}{c}\text { DRM } \\
\left(\text { g seedling-1 }^{(A)}\right.\end{array}$ & $\begin{array}{c}\text { DMA } \\
\left(\text { g seedling }^{-1}\right)^{(\mathrm{B})}\end{array}$ & DQI ${ }^{(B)}$ \\
\hline No irrigation & $2.85 \pm 0.40 \mathrm{~b}$ & $4.7 \pm 0.29 \mathrm{~b}$ & $2.26 \pm 0.21 \mathrm{~b}$ \\
\hline $60 \%$ FC & $5.26 \pm 0.93 \mathrm{a}$ & $17.5 \pm 4.20 \mathrm{a}$ & $6.32 \pm 1.25 \mathrm{a}$ \\
\hline $100 \% \mathrm{FC}$ & $5.73 \pm 0.87 \mathrm{a}$ & $17.6 \pm 3.74 \mathrm{a}$ & $5.2 \pm 0.82 \mathrm{a}$ \\
\hline CV (\%) & 33.5 & 55.9 & 45.7 \\
\hline
\end{tabular}

Different letters indicate significant differences according to ${ }^{(\mathrm{A})}$ Tukey or ${ }^{(\mathrm{B})}$ Kruskal-Wallis's test $(p<0.05)$. FC= field capacity of soil.

\subsection{Survival}

Seedling survival was significantly influenced by the hydrogel doses in the treatment without irrigation, showing an increasing linear trend $\left(\mathrm{R}^{2}=0.72\right)$. The absence of the hydrogel induced the survival reduction to $24 \%$, though it increased to $65 \%$ with the maximum dose (Figure 3 ), with no negative effect on growth, biomass accumulation, or seedling quality, as previously mentioned. This result can be attributed to the increase in the soil water retention capacity and its higher availability for seedlings with the presence of the hydrogel, given an intense and prolonged water deficit over time, without being phytotoxic with the maximum dose of $9 \mathrm{~g}$ per seedling. Navroski et al. (2015) pointed out that the increase in plant height and stem diameter during the production of $\mathrm{E}$. dunni seedlings in the nursery was related to the improvement of the substrate physical characteristics (i. e. porosity, water retention capacity), associated to the hydrogel application.

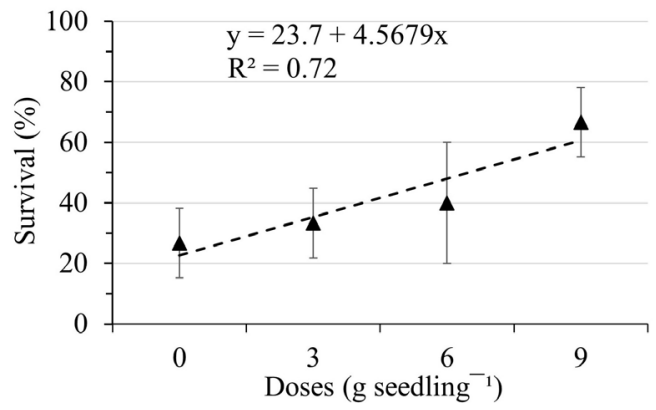

Figure 3. Survival of C. pyriformis seedlings under the absence of irrigation regimes after 20 weeks from transplant at bags according to different hydrogel doses. Bars indicate the standard deviation of the mean.
For six native savanna species in Brazil (Cerrado), the use of 1,000 $\mathrm{mL}$ of hydrogel solution ( 5 dry g per seedling) during planting in the dry season reduced the mortality of individuals from $41 \%$ to $26 \%$, but if planting occurs in the rainy season, its use is unnecessary (Fonseca et al., 2017). After the application of the same dose of hydrogel in the middle of the driest season in P. patula, the reduction in mortality dropped from $31 \%$ to $8 \%$, whereas at the beginning or the end, it was not significant (Mudhanganyi et al., 2018). Previous studies corroborate the fact that seedling survival is favored by the hydrogel when there is an intense and prolonged water deficit (Crous, 2017). Otherwise, as demonstrated for 30 tree species belonging to several successional stages, after a year of establishment in the field without water deficit, neither seedling growth nor survival were affected by the application of hydrogel (Barbosa et al., 2013).

The additional cost of using $9 \mathrm{~g}$ per seedling of hydrogel in C. pyriformis would be approximately COP $\$ 360$ (or $\$$ USD 0.10 , exchange rate in january 2021) per seedling. Further in depth financial analyses should be carried out in order to establish the ideal dose from an economic point of view. Moreover, as the abarco is considered to be a climax or late secondary species, factors such as tolerance to shading and drought should be explored in the future to provide an insight into the physiological and morphological adaptation mechanisms involved.

\subsection{Seedling wilting stages}

All visual categories of wilting stages were identified in the treatment in the absence of irrigation during the 20 weeks of evaluation (see Figures 4 and 5). Leave angle variation from $-45^{\circ}$ to $-90^{\circ}$ (with respect to the horizontal plane) was a key aspect to distinguish category 2 (wilted) and 
3 (severely wilted) (Figure 4C and 5D). Tyree et al. (2003) and Engelbrecht \& Kursar (2003) evaluated desiccation tolerance and its relationship with survival in the field as well as in a nursery for 28 tropical species in Panama, using the visual wilting stages applied in the current study, thus confirming its robustness.
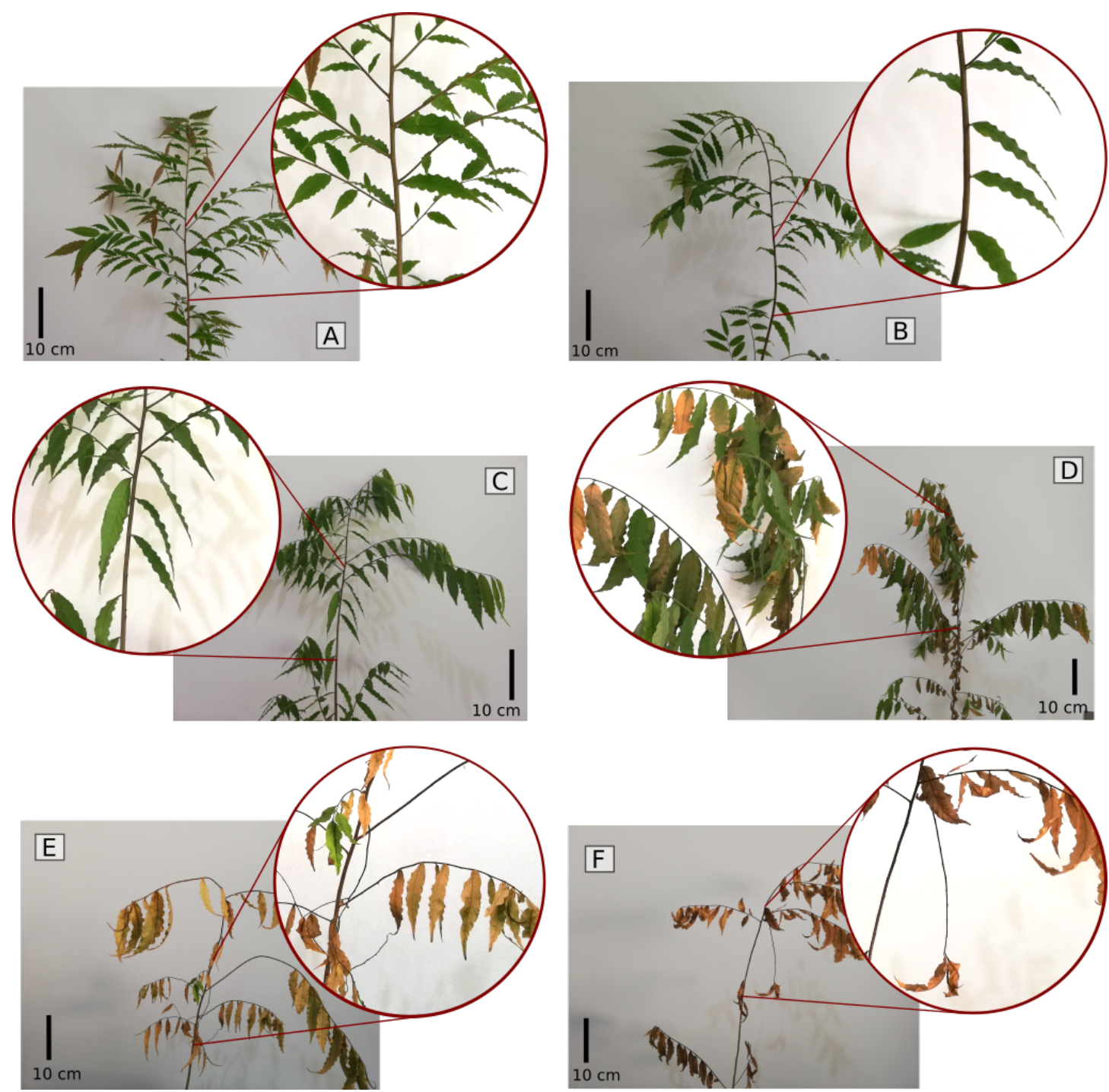

Figure 4. Symptoms of wilting stages of $C$. pyriformis seedlings classified in six categories. $0=$ normal $(A) ; 1=$ slightly wilted $(B) ; 2=$ wilted $(C)$; $3=$ severely wilted (D); $4=$ nearly dead $(E)$ and $5=$ dead $(F)$. scale bar $=10 \mathrm{~cm}$. Adapted from Engelbrecht $\& \operatorname{Kursar}(2003)$.

Seedlings showed no significant differences in category 0 (normal) according to the hydrogel doses used (duration of 39 to 47 days). The dose of $6 \mathrm{~g}$ per seedling kept the seedlings in category 1 (slightly wilted) for a more extended period, i.e., 29 days, while with the other doses, the period lasted 20 days (Table 4). Higher doses of the hydrogel induced the later onset of category 3 (wilted), that is, when the first symptoms of leaf necrosis appear. The duration of the categories 0 to 2 had the following relationship concerning the hydrogel doses: $0 \mathrm{~g}<6 \mathrm{~g}<3 \mathrm{~g}<9 \mathrm{~g}$ per seedling, that is, 93, 102, 100, and 109 days. The effect of water restriction could gradually reduce cell growth and expansion, and the loss of turgidity and flexibility of the cell wall in those first withering categories led to a scarce seedling support capacity (Le Gall et al., 2015).

Once the seedlings reached categories 3 (severely wilted) and 4 (nearly dead), the tendency towards mortality was almost irreversible, and therefore, there were no significant differences. At the end, category 5 (dead) was shorter with the dose of $9 \mathrm{~g}$ (4 days) followed by $6 \mathrm{~g}$ ( 9 days), although the latter showed no differences compared with the other hydrogel doses. 
Table 4. Mean values ( \pm standard deviation) for the duration, in days, of the visual wilting stages of $C$. pyriformis seedlings classified in six categories, from transplant up to 20 weeks.

\begin{tabular}{|c|c|c|c|c|c|c|}
\hline \multirow{2}{*}{$\begin{array}{c}\text { Hydrogel } \\
\left(\text { g seedling }^{-1}\right)\end{array}$} & \multicolumn{6}{|c|}{ Category (days) } \\
\hline & $0^{\text {ns }}$ & 1 & $2^{\text {ns }}$ & $3^{\text {ns }}$ & $4^{\mathrm{ns}}$ & 5 \\
\hline 0 & $39.1 \pm 1.4$ & $16.2 \pm 6.8 \mathrm{~b}$ & $37.7 \pm 3.7$ & $16.3 \pm 1.6$ & $12.1 \pm 2.1$ & $14.0 \pm 3.2 \mathrm{a}$ \\
\hline 3 & $46.1 \pm 2.9$ & $21.5 \pm 2.3 \mathrm{~b}$ & $34.9 \pm 5.9$ & $14.0 \pm 2.4$ & $10.3 \pm 2.9$ & $10.7 \pm 3 \mathrm{a}$ \\
\hline 6 & $41.1 \pm 4.5$ & $28.9 \pm 1.8 \mathrm{a}$ & $28.3 \pm 6.8$ & $16.3 \pm 1.6$ & $13.1 \pm 3.5$ & $9.3 \pm 3.6 \mathrm{ab}$ \\
\hline 9 & $47.6 \pm 0.8$ & $23.4 \pm 4.0 \mathrm{~b}$ & $38.7 \pm 5.3$ & $12.6 \pm 2.8$ & $12.1 \pm 3.5$ & $3.7 \pm 3.3 \mathrm{~b}$ \\
\hline CV (\%) & 7.8 & 16.6 & 15.1 & 12.6 & 12.0 & 39.3 \\
\hline
\end{tabular}

Different letters in the column indicate significant differences according to Tukey's test $(p<0.05)$. ns $=$ not significant. category $0=$ normal; $1=$ slightly wilted; $2=$ wilted; $3=$ severely wilted; $4=$ nearly dead; $5=$ dead. Adapted from Engelbrecht $\&$ Kursar (2003)

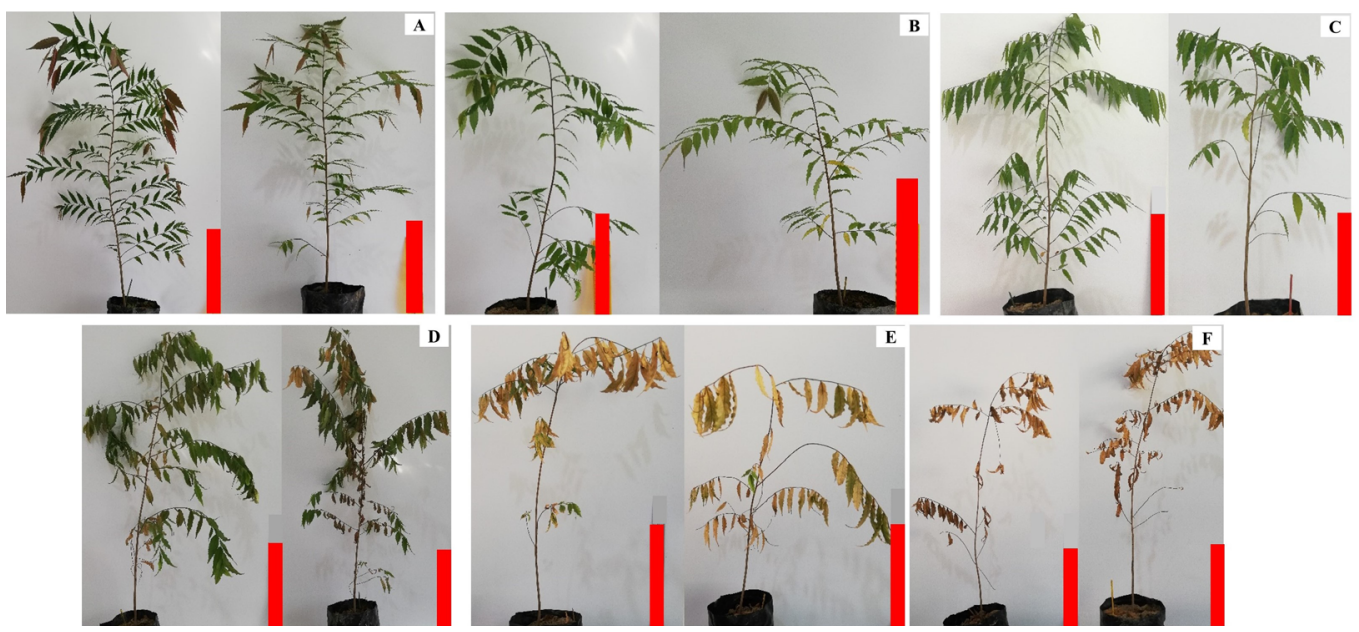

Figure 5. Symptoms of wilting stages of C. pyriformis seedlings classified in six categories, adapted from Engelbrecht \& Kursar (2003). $0=\operatorname{normal}(\mathrm{A}) ; 1=$ slightly wilted (B); $2=$ wilted $(\mathrm{C}) ; 3=$ severely wilted (D); $4=$ nearly dead (E) and $5=$ dead $(\mathrm{F}) . \mathrm{scale}$ bar $=25 \mathrm{~cm}$.

\section{CONCLUSIONS}

Under agricultural nursery conditions at $50 \%$ shading and using sandy loam soil for Cariniana pyriformis seedlings of five months of age, the following conclusions were obtained:

- After five months without irrigation, the application of $9 \mathrm{~g}$ per seedling of hydrated hydrogel increased the survival of seedlings from 24 to $65 \%$.

- Despite the increase in growth when $9 \mathrm{~g}$ per seedling of the hydrated hydrogel was applied, the benefits were not evident (including the effects on the biomass), when the soil is maintained at $60 \%$ or $100 \%$ of field capacity.

- The onset of wilting symptoms due to water stress tends to be delayed as the dose of hydrated hydrogel increases to $9 \mathrm{~g}$ per seedling.

\section{ACKNOWLEDGEMENTS}

The authors wish to thank AGROSAVIA, ascribed to the Ministry of Agriculture and Rural Development of Colombia (MADR), for funding this study. This work was part of the project "Strategies for forest plantation planning and management in Colombian agroecosystems". Particular thanks go to the Grupo de Estudios en Biodiversidad de la Universidad Industrial de Santander, as well as to the Herbarium UIS for continuous support.

\section{SUBMISSION STATUS}

Received: 05 Feb. 2020

Accepted: 18 Jan. 2021

Associate editor: Eduardo Vinicius da Silva (1)

\section{CORRESPONDENCE TO}

\section{Andrés Iván Prato}

Corporación Colombiana de Investigación Agropecuaria (AGROSAVIA), Centro de Investigación La Suiza, Km 32 via al mar, CEP 687519, Rionegro, Santander, Colombia

e-mail: aprato@agrosavia.co

\section{REFERENCES}

Agudelo-Castañeda GA, Cadena-Torres J, Almanza-Merchán PeJ, Pinzón-Sandoval EH. Desempeño fisiológico de nueve genotipos de cacao (Theobroma cacao L.) bajo la sombra de tres especies forestales en Santander, Colombia. Revista Colombiana de Ciencias Hortícolas 2018; 12(1): 223-232. 
Barbosa T, Rodrigues R, Couto H. Tamanhos de recipientes e o uso de hidrogel no estabelecimento de mudas de espécies florestais nativas. Hoehnea 2013; 40(3): 537-556.

Brucker M, Machado M, Benítez E, Carpenedo S, Turchetto F. Regímenes de riego y dosis de polímero hidroretenedor sobre características morfológicas y fisiológicas de plantas de Cordia trichotoma. Bosque 2017; 8(1): 123-131.

Cárdenas D, Castaño N, Sua S, Quintero L, Bernal M, Guerrero S et al. Planes de manejo para la conservación de abarco, caoba, cedro, palorosa y canelo de los andaquíes. 1st ed. Bogotá: Instituto Amazónico de Investigaciones Científicas - SINCHI; 2015.

Celis M. Cariniana pyriformis Miers. In Bernal R, Gradstein SR, Celis M (eds.). Catálogo de plantas y líquenes de Colombia. 1st ed. Bogotá: Universidad Nacional de Colombia (sede Bogotá); 2016.

Crous J. Use of hydrogels in the planting of industrial wood plantations. Southern Forests 2017; 79 (3): 197-213.

Dickson A, Leaf AL, Hosner JF. Quality appraisal of white spruce and white pine seedling stock in nurseries. The Forestry Chronicle 1960; 36(1): 10-13.

Engelbrecht BM, Kursar TA. Comparative drought-resistance of seedlings of 28 species of co-occurring tropical woody plants. Oecologia 2003; 136(3): 383-393.

Espitia M, Araméndiz H, Cardona C. Características morfométricas, anatómicas y viabilidad de semillas de Cedrela odorata L. y Cariniana pyriformis Miers. Agronomía Mesoamericana 2017; 28(3): 605-617.

Fonseca L, Roitman I, Jacobson T, Ogata R, Solari R, Ribeiro R. Viabilidade do hidrogel na recuperação de Cerrado sensu stricto com espécies nativas. Floresta e Ambiente 2017; 24: 1-8.

Gaburro TA, Zanetti LV, Gama VN, Dias CR, Faustini GR. Physiological variables related to photosynthesis are more plastic than the morphological and biochemistry in non-pioneer tropical trees under contrasting irradiance. Revista Brasileira de Botânica 2014; 38(1): 39-49.

IUCN. The IUCN Red List of Threatened Species (cited 2019). $<$ https://www.iucnredlist.org $>$

Le Gall F, Domon J, Gillet F, Pelloux J, Rayo C. Cell wall metabolism in response to abiotic stress hyacinthe. Plants 2015; 4 (1):112-166.

Markesteijn L, Poorter L. Seedling root morphology and biomass allocation of 62 tropical tree species in relation to drought- and shade-tolerance. Journal of Ecology 2009; 97(2): 311-325.

Mews CL, De Sousa JR, Azevedo GT, Souza AM. Efeito do hidrogel e ureia na produção de mudas de Handroanthus ochraceus (Cham.) Mattos. Floresta e Ambiente 2015; 22(1): 107-116.
Moreno MM, Del Valle J. Influence of local climate and ENSO on the growth of abarco (Cariniana pyriformis) in Chocó, Colombia. Trees 2015; 27(1): 97-107.

Mori SA, Smith NP, Cornejo X, Prance GT. Lecythidaceae. Bronx: The New York Botanical Garden Press - NYBG Science; 2019.

Mudhanganyi A, Ndagurwa HG, Maravanyika C, Mwase R. The influence of hydrogel soil amendment on the survival and growth of newly transplanted Pinus patula seedlings. Journal of Forestry Research 2018; 29(1): 103-109.

Navroski MC, Araujo MM, Fior CS, Cunha FD, Berghetti ÁL, Pereira, MD. Uso de hidrogel possibilita redução da irrigação e melhora o crescimento inicial de mudas de Eucalyptus dunnii Maiden. Scientia Forestalis 2015; 43 (106): 467-476.

Pelaez JJ, Prato AI, Zapata LP, Zaraté DA. Phenology of Cariniana pyriformis in the Magdalena Medio region of Santander, northeastern Colombia. Pesquisa Florestal Brasileira 2018; 38: 1-6.

Pizano C, García H (Eds). El bosque seco tropical en Colombia. 1st ed. Bogotá: Instituto de Investigación de Recursos Biológicos Alexander Von Humboldt; 2014.

Pontes Filho R, Gondim F, Costa M. Seedling growth of tree species under doses of hydrogel and two levels of luminosity. Arvore 2018; 42(1): $1-9$.

Prance GT, Mori SA. Lecythidaceae - Part I. The actinomorphic-flowered New World Lecythidaceae (Asteranthos, Gustavia, Grias, Allantoma \& Cariniana). Flora Neotropica Monographs 1979; 21(1): 1-270.

PROFOR. Informe final para el programa Colombia: Reforestación comercial potencial del Banco Mundial - PROFOR. Situación actual y potenciales de fomento de plantaciones forestales con fines comerciales en Colombia. 1st ed. Bogotá: Banco Mundial; 2017.

Salinas N, Cárdenas D. Abarco: Cariniana pyriformis. In: Cárdenas D, Salinas, S (eds.). Libro rojo de plantas de Colombia - volumen 4. Especies maderables amenazadas: primera parte. Serie libros rojos de especies amenazadas de Colombia. Bogotá: Instituto Amazónico de Investigaciones Científicas - SINCHI / Ministerio de Ambiente, Vivienda y Desarrollo Territorial: 2007.

Souza A, Guimarães RJ, Dominghetti A, Scalco MS, Rezende TT. Water-retaining polymer and seedling type when planting irrigated coffee. Ciencia Agronômica 2016; 47(2): 334-343.

Suarez JC, Melgarejo S, Casanoves F, Di Rienzo JA, Damatta FM, Armas C. Photosynthesis limitations in cacao leaves under different agroforestry systems in the Colombian Amazon. Plos One 2018; 13(11): 1-13.

Tyree MT, Engelbrecht B, Kursar T. Desiccation tolerance of five tropical seedlings in Panama. Relationship to a field assessment of drought performance. Plant physiology 2003; (132): 1439-1447. 